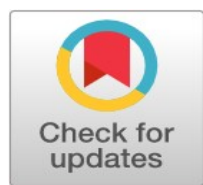

\title{
The influence of job career development opportunities, training, occupational safety and health on the job satisfaction of employees in the Telkom University
}

\author{
Helmina Ardyanfitri ${ }^{1}{ }^{*}$, Ratri Wahyuningtyas ${ }^{2}$ \\ 1, 2 Faculty of Economics and Business, Telkom University, Indonesia
}

\author{
Index Terms \\ Job \\ Career development opportunities \\ Training \\ Occupational safety and health \\ Job satisfaction \\ Employees
}

Received: 15 June 2016

Accepted: 27 August 2016

Published: 27 October 2016

\begin{abstract}
This paper aims to investigate the levels of job satisfaction of employees in Telkom University and determine the influence of job, career development opportunities, training, occupational safety, and health on job satisfaction of employees in Telkom University Indonesia. The sampling technique used in this study is stratified random sampling. This study is based on a questionnaire conducted with 214 respondents consisting of employees and Lecturers in Telkom University, Indonesia. The job satisfaction levels of the employees were found to be high. Hypothesis testing using the F-test showed that job, career development opportunities, training, occupational safety, and health significantly influenced job satisfaction. However, based on partial results of hypothesis testing, variables that significantly influence job satisfaction at the Telkom University are job, career development opportunities, and training, while occupational safety and health do not affect the job satisfaction of employees. This study shows employees' job satisfaction levels and determines the influence of job, career development opportunities, training, occupational safety, and health on job satisfaction of employees in Telkom University, Indonesia. Hence the results from this study can help the Telkom University to increase the satisfaction level.
\end{abstract}

(C) 2016 The Author(s). Published by TAF Publishing.

\section{INTRODUCTION}

The process of globalization cannot be separated from a change, the changes that occur in the various sectors and aspects of people`s lives. The changes also impact on competition in the world of work. Competition in the world of work is higher and so quick for institutions and organizations, including educational institutions such as colleges. Telkom University was established on August 14, 2013. Telkom University is a Private University organized by Telkom Education Foundation, it is a merger of four Private Universities, that is Telkom Institute of Technology
(IT Telkom), Institute of Management Telkom (IM Telkom), Polytechnic of Telkom, and School of The Art and Design Telkom Indonesia. So Telkom University is faced with new conditions. Organizational changes have been done that suggest Telkom University to present as a private university ready to compete with state institutions or other private ones. 2015 is the second year of Telkom University contributing to the nation through the Tri Dharma activities. In order to be able to manage on their own, Telkom University has higher levels of competitiveness, as well as quality, then one of the components of resources that determines

\footnotetext{
${ }^{*}$ Corresponding author: Helmina Ardyanfitri

†Email: helminardyan@gmail.com
} 
the quality of service of a higher education institution is its human resources. It's not easy maintaining high competencies of human resources as well as corresponding to the company wanted, one way of retaining employees is by way of paying attention to their job satisfaction. Job satisfaction of Employee is an important attribute that organizations desire of their staff (Oshagbemi, 2003). Job satisfaction is one criterion for establishing the health of an organization; rendering effective services largely depends on the human resources (Brignall, Fitzgerald, Johnston\& Silvestro, 1991) and job satisfaction experienced by employees will affect the quality of service they render. Consequently, satisfaction of the employees in higher education institutions is a very important issue (Küskü, 2003). The impact of other variables on efficiency, such as infrastructures and internal relationships, should also be recognized. Job satisfaction has been defined as a positive emotional state resulting from the pleasure a worker derives from the job (Locke, 1969). However, job satisfaction of employee at Telkom University has not been achieved, because dimension indicators of job satisfaction that consist of the job, career development opportunities, training, occupational safety and health are realized and unrealized in the faculty.

\section{LITERAT URE REVIEW \\ Job}

The job characteristics model (JCM), and the social information processing model have been offered to explain how various characteristics or dimensions of a job can intrinsically motivate individuals, and increase their levels of job satisfaction and job performance. Hackman \& Oldham's (1974) job characteristics model suggests that five core job dimensions affect certain personal and work-related outcomes, including work motivation and job satisfaction. The five core job dimensions they identified are autonomy, feedback, skill variety, task identity, and task significance. Autonomy has been defined by Hackman \& Oldham (1974) as the degree to which a job provides freedom, independence, and discretion. They defined feedback as the degree to which an individual obtains direct and clear information about his/her performance effectiveness. Skill variety has been defined as the degree to which an individual is required to use a number of different skills and talents to perform a variety of different activities. They define task identity as the degree to which the job requires completion of a whole and identifiable piece of work. Task significance has been defined as the degree to which the job has a substantial impact on the lives or work of others. Job character- istics play an important role in lessening levels of turnover intention. However, the extent to which job characteristics affect turnover intention varies as a function of satisfaction of employees with their work context (Ghosh, Rai, Chauhan, Gupta \& Singh, 2015). The relationship between job satisfaction and job specialties is job satisfaction is increased in line with rising specialization, and then an additional specialization leads to decreased job satisfaction. Job satisfaction declines because of a lack of autonomy, variety, and identity of the task. This is consistent with research conducted by Anderson (1984) and Colarelli, Dean \& Konstans (1987) in Friday \& Friday (2003) that shows that there is a significant relationship between the variables of a variety of skills, task identity, task significance, autonomy, and feedback on job satisfaction. (Luthans, 2008:145). Congruency with the skills and ability to work of the employee is expected to encourage employees to produce a good performance.

\section{Career Development Opportunities}

Career development is a better career plan as revealed by Handoko (1995:123) that career development is a personal improvement to accomplish a career plan. Rivai (2008:290) suggests that the career development is the process of improving the ability of individual work that is accomplished in order to achieve desired career. Siagian (2014:203) suggests that career development is that every employee should have a clear picture of the highest rungs of what can be achieved as long as they display a satisfactory performance. Based on the description above definition of expert opinion, it can be concluded that career development is a process of activities to improve the working ability of individuals to plan a career in the present and future. In order to determine the career path, career goals, and career development opportunities that can be taken, the employee needs to consider five factors (Siagian,2014:207), that is fair treatment in a career that can only be realized if the criteria for promotion are based on objective considerations, rationale, and widely known among employees; Concerns direct superior where direct superior involvement in planning the career respectively; Information about the various promotional opportunities for employees to access information about various opportunities to be promoted; Interests to be promoted in terms of fostering the interests of workers for career development in a way that is flexible and proactive; The level of satisfaction that everyone wants to achieve is the progress included in the demanding careers, a measure of success that is used is different. 
These differences are due to a person`s satisfaction levels that differ as well.

Career development opportunities are important that management can improve productivity, improve employee attitudes to work and build a higher job satisfaction (Rivai, 2008:299). The relationship between job satisfaction and career development is that job satisfaction of employees will increase in line with their career development opportunities that are designed through career development programs and career needs. This is consistent with research conducted by Chen, Chang \& Yeh (2004) that showed a bigger gap between the level of career development programs and career need resulting in the dissatisfaction of employees.

\section{Training}

Training is a concerted effort by the company (organization) to facilitate the learning competencies of employees associated with the job (Sudarmanto, 2009:228). Mangkunegara (2009:44) suggests that training is a shortterm educational process that uses systematic and organized procedure where non-managerial employees learn the knowledge and technical skills in the limited purpose. Job training is to give the overall activities, acquire, enhance, and develop job competence, productivity, discipline, attitude, and work ethics at a certain level of skill and expertise in accordance with the level and qualification of office or employment (Marwansyah, 2012:155). Based on the description above definition of expert opinion, it can be concluded that training related to the improvement of knowledge, skills, competencies and behaviors of employees is related to the current job or position in carrying out the work effectively. One purpose of the training and development is to reduce turnover, absenteeism and increase job satisfaction (Rivai, 2008:229). Choo \& Bowley (2007) explained that the effectiveness and efficacy of a training program are dependent on evaluation of training quality, course design and learning experience. Next, employee satisfaction is found to be influenced by work environment, company values and job responsibilities.

\section{Occupational Safety and Health}

Occupational health and safety refer to the physiological conditions and psychological-physical labor that is provided by the company. If a company carrying out the actions of occupational safety and health is effective, then fewer workers will suffer from injuries or illnesses of short term and long term as a result of their work in the com- pany (Rivai, 2008:41). Marwansyah (2012:378) states that safety is the protection of workers from injuries caused by accidents related to employment, while occupational health are spared from physical or emotional illness. Occupational health includes occupational health service, prevention of occupational diseases, and occupational health requirements. Based on the description above definition of expert opinion, it can be concluded that the occupational safety and health is an attempt to prevent unwanted conditions of labor, both the physical-physiological and physiological conditions in order to be always safe and to avoid injury or disease while performing the job. With Occupational safety and health, employee satisfaction can be realized. Good working conditions (an environment that is safe, healthy, clean and attractive), as well as guaranteed safety of employees will then arise in the employee satisfaction, which can be seen in the attitude of the employees who are enthusiastic about working. Conversely, the unpleasant working conditions will have an impact anyway. If there are good conditions, then there will be no problems with job satisfaction, otherwise if there are bad conditions there will be bad impact on job satisfaction (Luthans, 2008:146). The physical, chemical, socio-psychological and biological factors have a considerable effect on the job satisfaction. The most important factors on the job satisfaction are the biological and chemical risk factors. It is expected that as long as the risk level on the occupational health and security increases the satisfaction level of the employees will accordingly decrease (Kilic \& Selvi, 2009).

\section{Job Satisfaction}

Robbins (2007:103), job satisfaction refers to the general attitude of an individual towards his job. Rivai (2008:475), job satisfaction is an evaluation that describes someone on a feeling of being happy or not happy for his attitude, satisfied or not satisfied in working. Siagian (2014:295) argues that job satisfaction is someone`s point of view, both of which are positive or negative about his work. Hasibuan (2013:202), job satisfaction is a pleasant emotional attitude and love for the job. This attitude is reflected by the morale, discipline, and work achievement. Job satisfaction is enjoyed in the work, out of work, and the combination of both of them. Indicators of job satisfaction can be measured by the disciplinary, morale and small turnover. Thus the job satisfaction of employees is relatively good if discipline, morale, and turnover are small. Conversely, if the discipline, morale, and employee turnover are greater, then the job satisfaction of employees in the company is 
less (Hasibuan, 2013:199).In the case of Turkey, (Küskü, 2003) explored the differences in satisfaction dimensions between the academic and administrative staff in higher education institutions. On the other hand, Cagliyan (2007) investigated the effect of burnout on job.

\section{CONCEPTUAL FRAMEWORK}

Based on the theories of various experts that have been described previously, this study focused to research the influence of job, career development opportunities, training, occupational safety and health in the Telkom University. Figure -1 is the framework of this study.

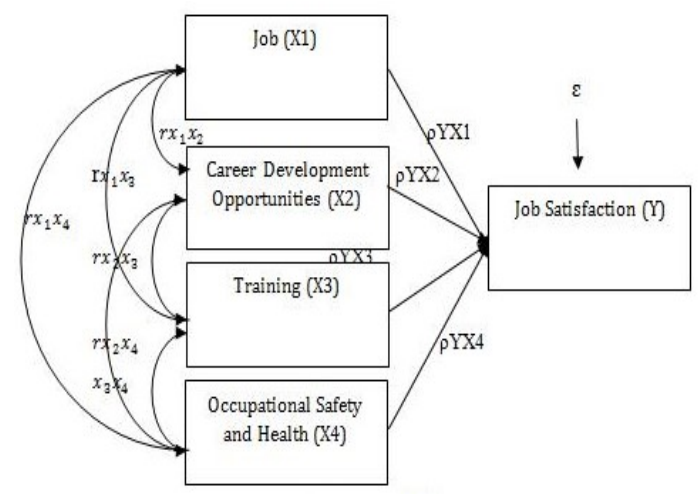

FIGURE 1. Framework

Based on the research model, it can be formulated as the hypotheses of this study, as follows:

H1: Job has a positive effect on job satisfaction in the Telkom University.

H2: Career Development Opportunities have a positive effect on job satisfaction in the Telkom University.

H3: Training has a positive effect on job satisfaction in the Telkom University.

H4: Occupational Safety and health have a positive effect on job satisfaction in the Telkom University.

H5: Job, Career Development Opportunities, Training,
Occupational Safety and health have a positive effect on job satisfaction in the Telkom University simultaneously.

\section{RESEARCH METHODOLOGY}

\section{Research Design}

This research study is aimed to find out and investigate the levels of job satisfaction of employees in the Telkom University and to determine the influence of job, career development opportunities, training, occupational safety and health on job satisfaction of employees in Telkom University, Indonesia. This study is cross-sectional and hypothetical approach study.

\section{Sample \& Respondents}

The sampling technique used in this study is stratified random sampling and this study based on a questionnaire was conducted with 214 respondents consisting of employees and Lecturers in Telkom University, Indonesia.

\section{Procedure and Analysis}

The questionnaire for survey was self-governed and in person disseminated by the researcher among the respondents for the study. Analysis of data was done with quantitative tools and techniques in this study used statistical package for social sciences (SPSS) and path analysis technique.

\section{RESULTS AND FINDINGS}

The table 1 shows the internal consistency and reliability of the variables. Cronbach`s coefficient alpha, which measures how well the variables positively relate to one another, was generated by using SPSS software.

The reliability is measured by calculating Cronbach alpha and the value ranges from 0.6 to 0.9 . As the value is close to 0.7 to 0.8 , the reliability is considered to be at goodness level. The values in the lower table show that the values fall within the prescribed range and having strong internal consistency with the items to be measured:

TABLE 1. Reliability of variables

\begin{tabular}{lc}
\hline Variables & Cronbach Alpha \\
\hline Job & 0.910 \\
Career Development Opportunities & 0.836 \\
Training & 0.879 \\
Occupational Safety and Health & 0.924 \\
Job Satisfaction & 0.923 \\
\hline \hline
\end{tabular}

The table 2 shows the distribution of characteristics of respondents of this study $(n=214)$. The table 3 shows that the hypothesis made on the basis of literature review and theories in support of the study variables is tested by ap- 
TABLE 2 . Distribution of characteristics of respondents

\begin{tabular}{lccc}
\hline \hline Distribution & Group & F & \% \\
\hline Sex & Male & 134 & $63 \%$ \\
& Female & 80 & $37 \%$ \\
Education Level & Total & 214 & $100 \%$ \\
& Diploma (D-3) & 8 & $4 \%$ \\
& Bachelor Degree (S-1) & 29 & $13 \%$ \\
& Master Degree (S-2) & 148 & $69 \%$ \\
& Doctor Degree (S-3) & 29 & $14 \%$ \\
Age & Total & 214 & $100 \%$ \\
& Range 0-25 & 0 & $0 \%$ \\
& Range 26-30 & 47 & $22 \%$ \\
& Range 31-40 & 106 & $50 \%$ \\
Employment Period & $\geq 41$ and over & 61 & $28 \%$ \\
& Total & 214 & $100 \%$ \\
& $<5$ year and less & 95 & $44 \%$ \\
& 5-10 year & 89 & $42 \%$ \\
& $11-15$ year & 21 & $10 \%$ \\
& $>15$ year and over & 9 & $4 \%$ \\
Profession & Total & 214 & $100 \%$ \\
& Employees & 37 & $17 \%$ \\
& Lecturers & 177 & $83 \%$ \\
& Total & 214 & $100 \%$ \\
\hline
\end{tabular}

plying path analysis technique. Partial hypothesis testing is done by comparing the significance value obtained through calculation of SPSS by calculating the value of $t$, the criteria is t-test $>\mathrm{t}$-table. $\mathrm{H} 0$ rejected; $\mathrm{H} 1$ accepted by Dk (degree of freedom) $=\mathrm{n}-2,214-2=212$, and the result of $\mathrm{t}$-table is 1,971 , $t$ hypothesis testing criteria are as follows:

If $\mathrm{t}$-test $>\mathrm{t}$-table, then $\mathrm{H} 0$ rejected and $\mathrm{H} 1$ accepted If $\mathrm{t}$-test $>\mathrm{t}$-table, then $\mathrm{H} 0$ accepted and $\mathrm{H} 1$ rejected To determine the significance, these criteria are as follows: If sig $<0.05$, then significant If sig $>0.05$, then not significant

The first hypothesis is accepted on the basis of T-Test value that is 4.492 and the p-value is less than 0.05 which depicts that the job has positively significant impact on the job satisfaction. Based on the beta value, the job has $29.3 \%$ impact on the job satisfaction which briefs that if there is $1 \%$ change in the job then $29.3 \%$ change will be seen in the job satisfaction and any change in job precludes the same directional change in the job satisfaction. The second hypothesis is accepted on the basis of T-Test value that is 3.950 and the $\mathrm{p}$-value is less than 0.05 which depicts that the career development opportunities have positively significant impact on the job satisfaction. Based on the beta value, the career development opportunities have $28.2 \%$ ISSN: 2414-309X DOI: $10.20474 /$ jabs-2.5.3 impact on the job satisfaction which briefs that if there is $1 \%$ change in the career development opportunities then $28.2 \%$ change will be seen in the job satisfaction and any change in career development opportunities precludes the same directional change in the job satisfaction.

The Third hypothesis is rejected on the basis of T-Test value that is 1.907 and the $p$-value is more than 0.05 which depicts that the training has no positively significant impact on the job satisfaction. Based on the beta value, the training has $11.6 \%$ impact on the job satisfaction which briefs that if there is $1 \%$ change in the training then $11.6 \%$ change will be seen in the job satisfaction and any change in training precludes the same directional change in the job satisfaction.The forth hypothesis is rejected on the basis of T-Test value that is 1.342 and the p-value is more than 0.05 which depicts that the occupational safety and health have no positively significant impact on the job satisfaction. Based on the beta value, the occupational safety and health have $8.3 \%$ impact on the job satisfaction which briefs that if there is $1 \%$ change in the occupational safety and health then $8.3 \%$ change will be seen in the job satisfaction and any change in occupational safety and health precludes the same directional change in the job satisfaction. 
TABLE 3. Hypothesis testing

\begin{tabular}{lcccc}
\hline Path & T-test & P-value & Beta value & Supported/unsupported \\
\hline Job $\rightarrow$ Job Satisfaction & 4.492 & $<0.05$ & 0.293 & Supported \\
Career Development Opportunities $\rightarrow$ Job Satisfaction & 3.950 & $<0.05$ & 0.282 & Supported \\
Training $\rightarrow$ Job Satisfaction & 1.907 & $>0.05$ & 0.116 & Unsupported \\
Occupational Safety and Health $\rightarrow$ Job Satisfaction & 1.342 & $>0.05$ & 0.083 & Unsupported \\
\hline \hline
\end{tabular}

To determine the effect of independent variables on the dependent variable in this study, researcher then conducted simultaneous hypothesis testing. Hypothesis testing is done by observing the significance value obtained through calculation of SPSS by calculating the value of F and using the ANOVA Table to compare values of F-Test with F-Table. Values of degree of freedom (DF) with numerator $=4$; denumerator $=209$, then the F-table result is 2.41. Specified criteria for decision-making results of hypothesis testing are as follows:

a) If $\mathrm{F}$ test $>\mathrm{F}$ table, then $\mathrm{H} 0$ rejected and $\mathrm{H} 1$ accepted.

b) If $\mathrm{F}$ test $<\mathrm{F}$ table, then $\mathrm{H} 0$ accepted and $\mathrm{H} 1$ rejected.

The Result with SPSS obtained for F-test is $27.547>$ Ftable is 2.41 so that the fifth hypothesis is accepted and the p-value is less than 0.05 which depicts that the job, career development opportunities, training, occupational safety and health have positively significant impact on the job satisfaction simultaneously. Based on the R-Square, the magni tude of the influence of elements of job, career development opportunities, training, occupational safety and health is $34.5 \%$ while the remaining $65.5 \%$ is influenced by other variables outside of this research.From the results of the partial hypothesis testing presented in table 3 is the result of variables of training and occupational safety and health that have no significant effect, the test model should be improved by testing model through trimming test. Riduwan \& Ahmad (2007:127), trimming test is a model used to correct a structural analysis model of the path by removing the exogenous variables that are not significant of the model. How to use a model that calculates the coefficients trimming path without exogenous variables includes path coefficient that is not significant. In this study variable of the occupational safety and health has a smaller coefficient than the variable of training, then the occupational safety and health are removed first. The results of hypothesis after trimming test are shown in the table 4.

TABLE 4. Hypothesis after Trimming test

\begin{tabular}{lcccc}
\hline \hline Path & T-test & P-value & Beta value & Supported/unsupported \\
\hline Job $\rightarrow$ Job Satisfaction & 4.637 & $<0.05$ & 0.301 & Supported \\
Career Development Opportunities $\rightarrow$ Job Satisfaction & 4.519 & $<0.05$ & 0.309 & Supported \\
Training $\rightarrow$ Job Satisfaction & 2.008 & $<0.05$ & 0.122 & Supported \\
\hline \hline
\end{tabular}

The first hypothesis is accepted on the basis of T-Test value that is 4.637 and the $p$-value is less than 0.05 which depicts that the job has positively significant impact on the job satisfaction. Based on the beta value, the job has 30.1\% impact on the job satisfaction which briefs that if there is $1 \%$ change in the job then $30.1 \%$ change will be seen in the job satisfaction and any change in job precludes the same directional change in the job satisfaction.

The second hypothesis is accepted on the basis of T-Test value that is 4.519 and the p-value is less than 0.05 which depicts that the career development opportunities have positively significant impact on the job satisfaction. Based on the beta value, the career development opportunities have $30.9 \%$ impact on the job satisfaction which briefs that if there is $1 \%$ change in the career development opportunities then $30.9 \%$ change will be seen in the job satisfaction and any change in career development opportunities precludes the same directional change in the job satisfaction.

The Third hypothesis is rejected on the basis of T-Test value that is 2.008 and the $p$-value is less than 0.05 which depicts that the training has positively significant impact on the job satisfaction. Based on the beta value, the training has $12.2 \%$ impact on the job satisfaction which briefs that if there is $1 \%$ change in the training then $12.2 \%$ change will be seen in the job satisfaction and any change in training precludes the same directional change in the job satisfaction. The result of F-test after trimming test is 35.992 $>$ F-test result is 2.41 and the p-value is less than 0.05 so that the job, career development opportunities and training have positively significant impact on the job satisfaction simultaneously. Basis on the R-Square, the magnitude of the influence elements of job, career development opportu- 
nities, training, occupational safety and health is 34\% while the remaining $66 \%$ is influenced by other variables outside of this research. Following the trimming test, model can in figure - 2. The following is a table of the influence of direct, indirect, and total influence of $\mathrm{X} 1, \mathrm{X} 2$, and $\mathrm{X} 3$ against Y:

be seen from the calculation of the overall path analysis

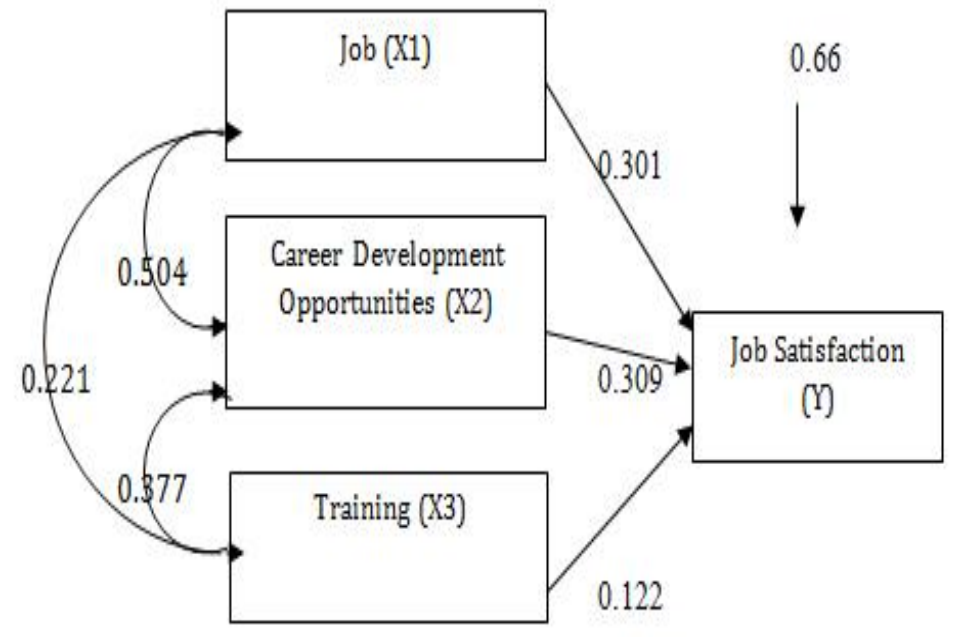

FIGURE 2. Path analysis model after Trimming

TABLE 5 . Shows means, standard deviation of in intention to use mobile application and technology acceptance factors

\begin{tabular}{lccccc}
\hline \hline Variable & Directly influences & \multicolumn{3}{c}{ Simultaneously influences } & Total influences against Y \\
\hline \multicolumn{7}{c}{ X1 } & $\mathrm{X} 1$ & $\mathrm{X} 2$ & $\mathrm{X} 3$ & \\
$\mathrm{X} 2$ & - & 0.05 & 0.01 & 0.15 \\
$\mathrm{X} 3$ & 0.09 & 0.05 & - & 0.01 & 0.16 \\
Total Influences of X1, X2, and X3 against Y & -0.01 & 0.03 \\
\multicolumn{7}{l}{ Influence Factor Of Residual } \\
\hline \hline
\end{tabular}

\section{DISCUSSION AND CONCLUSION}

Based on the analysis of the characteristics of the respondents in this research, gender is dominated by Men amounting to $63 \%$, based on the age of the respondents was dominated by the age range of $31-40$ years amounting to $50 \%$, based on the profession, $83 \%$ of respondents are lecturers, based on the education level, $68 \%$ of respondents are Master's and Bachelor's (S2) and based on the employment period of respondents, it amounted to $44 \%$ having less than five years. Job satisfaction in Telkom University is high as seen from a high level of discipline where the employees always comply to all regulations in Telkom University, next as seen from the morale of an employee where the employee is always respectful of his superior, as well as views that turnover has small rate because loyalty of employee is very high against the Telkom University indicating the presence ISSN: 2414-309X of the employment period range $>15$ years to $4 \%$ and range 11-15 years to $10 \%$. Job satisfaction of Employee is shown against the loyalty of employees which are marked with a small turnover, at Telkom University mostly new employees entering are employees who replace the position of employees who came out not because they stopped working but rather employees retired. It shows that the turnover rate is very small, so the job satisfaction at The Telkom University is high. The results in this study obtained influence four independent variables that were tested simultaneously and partially. The results of testing simultaneously showed the influence of job, career development opportunities, training, occupational safety and health against job satisfaction that have significant effect simultaneously. The results of total influence are four independent variables which are 
variables of job, career development opportunities, train

ing occupational safety and health against the job satisfaction in Telkom University accounting for 34\%.The results of the partial counting of the four independent variables concluded that job (X1), career development opportunities (X2), and training (X3) have significant effect on job satisfaction in the Telkom University partially. Variable of career development opportunities (X2) has total influence against job satisfaction amounting to $16 \%$. This indicated that the majority of the age of the respondents was in the age range of 30-40 years who are at an advanced phase in which this age focuses on the achievement, self-esteem, and freedom. Advanced phase at this stage of his career was the promotion so that employees will be vying to meet those needs by way of a chance to develop their career so the use of an indicator variable of career development opportunities is already dominant in influencing job satisfaction directly impacting job satisfaction of employees.

This finding is reinforced by the results of previous research, entitled "Career Development an Imperative of Job Satisfaction and Career Commitment: Empirical Evidence from Pakistani Employees in Banking Sector" which states that career development opportunities have a positive significant effect on job satisfaction of employees so that it can be said in everyday life career development has a direct impact on achievement of job satisfaction and career dedication (Saleem, Kamran, Sabir \& Iqbal, 2013).Variable of job (X1) has total influence against job satisfaction amounting to $15 \%$. It is shown that the respondents of this study consisted of lecturers and employees, the majority of respondents were lecturers where the workload between lecturers and employees was different to be adapted to their respective professional work if employees receive a workload that does not match the capabilities it will create a feeling of dissatisfaction. So the work has a direct impact on job satisfaction. This finding is reinforced by the results of previous research "Exploring The moderating Of context satisfaction between job characteristics and turnover intention of employees of Indian public sector banks" that argues that the job characteristics significantly influence job satisfaction. Whereas the context of the satisfaction is important to build a positive environment to reduce employee intention to quit (Ghosh, et.al. 2015). Variable of training (X3) has total influence against job satisfaction amounting to $3 \%$. Based on employment period, the respondents were dominated by ones with less than five years of experience where experiential working is low so that training is re- quired for the employees that can increase knowledge and competence of employee in order to be ready to contribute to the activities of the Tri Dharma in Telkom University. It shows that effective training is required and can directly affect job satisfaction.

This finding is reinforced by the results of previous research "Using Training and Development to Affect Job Satisfaction Within Franchising" that argues that the effectiveness and efficacy of the training program depend on the evaluation of the quality of training, design training and learning experiences significantly influencing job satisfaction (Choo \& Bowley, 2007). Variable of occupational safety and health (X4) has no effect against job satisfaction. It is shown that the majority of respondents are lecturers where the level of safety that consists of physical factors (temperature, humidity, light, and radiation), chemical factors (chemical gases are flammable and hazardous explosions), biology (diseases that come from microbes) is low, so the risk level of safety and health at the Telkom University is low than other companies in operation directly related to chemicals where levels of safety and health risks are so high that require extra safety equipment for the protection of employees.

\section{RECOMMENDATIONS}

In addition to these results, we can produce some solution and recommendations in the light of the knowledge and theory based on this research:

\section{Career Development Opportunities}

Variable of career development opportunities (X2) has a positive effect on job satisfaction. This indicated that the majority of the age of the respondents was in the age range of 30-40 years who are at an advanced phase in which this age focuses on the achievement, self-esteem, and freedom. Advanced phase at this stage of his career was the promotion. For that the University needs to estimate the needs of the employees of the Telkom by following the seminars, career or career guidance counselling. So employees are able to measure the perceived career needs in organizations (Telkom University) where employees have a desire to work and develop into a better person, here the role of the organization is needed to help steer in taking decisions and give advice, then University of Telkom should give input in the form of advice, suggestions, or instructions. After estimating the needs of career of employees, the University of Telkom needs to provide facilities that can help organize employees to plan their career. The facilities may include 
career information, career counseling or workshops. This facility not only helps as a means of disseminating the management policy in General, but also helps each employee for knowing the direction of the path of his career. In addition employees can know the career opportunities that exist within the Telkom University clearly about the various possibilities of the post that can be occupied. Promotion conducted in Office must be clear and transparant in order to give the same chance to all sides then Telkom University needs a Job Tender. Job Tender is one way of filling in the structural position by providing broad and equal opportunities for all parties, is announced publicly and on the basis of selection against the potential and competence that are owned and tailored in terms of Office. As for the implementation, a Job Tender is as follows:

1) Inventory of existing structural vacancy with the requirements of his position.

2) Job structural positions informed throughout each faculty.

3) Based on the Dean proposing candidates who meet the requirements.

4) Furthermore, the selection process.

In conducting the Job Tender, Telkom University can develop a fair competition, help employees to determine their career, improve motivation, and increase employee satisfaction.

\section{Job}

The work has an impact on job satisfaction in Telkom University. Telkom University can provide a more challenging job in order to motivate employees and increase job satisfaction of employees by holding job rotation so that the employee is placed on work that is not appropriate expertise or field, provide more workload than usual and produce a work deadline. The variety of skills of employees increases, so Telkom University can improve the competence of employees by organizing coaching and competence development through seminars, comparative studies, teamwork, and other programs. Subsequently Telkom University needs to provide feedback that may be material and nonmaterial on the achievement of the job, such as for material example, provides benefits research (lecturer), remuneration, the chance of further studies at the cost of college while in the form of non-material, for example, evaluation performance results, congratulations from superiors etc. Providing feedback to employees can build satisfaction and employee performance at work.

\section{Training}

Training has an influence on job satisfaction at the Telkom University. Based on characteristics of the respondents, employment period is less than five years and the majority of respondents are lecturers so Telkom University needs a training program tailored to the needs of employees so that lecturers can contribute in the activities of Tri Dharma effectively. For that Telkom University is required to assess the need to determine the current problems and future needs can be met by the training and development program. Steps should be taken by Telkom University in assessing training needs that are as follows:

1) Collect data to determine the scope of work training.

2) Compose the target task description of the work or activity with a specified target,

3) Measuring instrument to measure the ability of the work. 4) Implement measurement capability ratings at work.

5) Process measurement data and interpret the results of data processing.

6) Establish training needs ratings.

Furthermore, Telkom University must do selection of coaches who will provide materials to employees, where the coach plays an important role in the advancement of employees to be developed. There are some coaches who will carry out the development as internal trainers, external trainers, and internal and external combined. Universities need to sort out a coach based on specific qualifications that are different from other positions and have a special certificate in the field of training and trainers have to qualify the terms of the coach is the ability to teach, communicate, and social, personal authority, competent technical and emotional stability. By sorting trainer for training expected employee training materials can be understood well.

\section{Occupational Safety and Health}

Occupational Safety and Health have no influence on job satisfaction at the Telkom University. Telkom University should pay attention the occupational safety and health by providing facilities that are tailored to the needs of employees with regard to existing procedures. For example adequate P3K facilities at each work unit in the Telkom University.

\section{FUTURE RESEARCH}

Recommended for other researchers to conduct research on other factors that can affect job satisfaction as compensation, supervision, co-workers, and other factors.This study focuses only on the Telkom University, we recommend that 
further research can take a sample of a more specific example, just doing research on work satisfaction in one or more faculties in order to focus, hopefully, can provide benefits on job satisfaction, it can make the problem by providing

\section{REFERENCES}

Anderson, C.H. 1984. Job design: Employee satisfaction and performance in retail stores. Journal of Small Business Man- agement, 22: 9-17.

Brignall, T.J., Fitzgerald, L., Johnston, R., \& Silvestro, R. 1991. Performance measurement in service businesses. Manage- ment Accounting, 69(10): 34-40.

Colarelli, S.A.I., Dean, R.A. \& Konstans, C. 1987. Comparative effects of personal and situational influences on job outcomes of new professionals. Journal of Applied Psychology, 72: 558-566.

Cagliyan., Y. 2007. Burnout syndrome and it's effects on job satisfaction (a field research on state and vakif universities academicians). Unpublished master's thesis, Kocaeli University, Kocaeli, TR.

Chen, T.Y., Chang, P. L., \& Yeh, C.W. 2004. A study of career needs, career development programs, job satisfaction and the turnover intentions of R\&D personnel. Career Development International, 9(4): 424-437.

DOI: $10.1108 / 13620430410544364$

Choo, S., \& Bowley, C. 2007. Using training and development to affect job satisfaction within franchising. Journal of Small Business \& Enterprise Development, 14(2): 339-352. D0I: 10.1108/14626000710746745

Friday, S.S., \& Friday, E. 2003. Racioethnic perceptions of job characteristics and job satisfaction. Journal of Management Development,22(5): 426-442. D0I: 10.1108/02621710310474778

Ghosh, P., Rai, A., Chauhan, R., Gupta, N., \& Singh, A. 2015. Exploring the moderating role of context satisfaction between job characteristics and turnover intention of employees of Indian public sector banks. Journal of Management Develop- ment, 34(8): 1019-1030. DOI: 10.1108/JMD-10-2014-0138

Hackman, J.R., \& Oldham,G.R. 1974. The job diagnostic survey: An instrument for the diagnosis of jobs and the evalua- tion ofjob redesign projects. Wo rking paper no. 4, Departement of Administrative Sciences, Yale University, New Haven, US. Handoko, H.T. 1995. Personnel and human resources management. Yogyakarta, ID: BPFE.

Hasibuan., M . 2013. Human resources management. Jakarta, ID: PT. Bumi Aksara.

Kilic, G., \& Selvi, M.S. 2009. The effects of occupational health and safety risk factors on job satisfaction in hotel enterprises. Ege Academic Review, 9(3): 903-921.

Küskü, F. 2003. Employee satisfaction in higher education: The case of academic and administrative staff in Turkey. Career Development International, 8(7): 347-356. DOI: 10.1108/13620430310505304

Locke, E.A. 1969. What is job satisfaction? Organizational Behavior and Human Performance, 4(4): 309-336. D0I: 10.1016/0030-5073(69)90013-0

Luthans., F. 2008. Organizational behaviour. New York, NY: McGraw Hill Companies, Inc. Mangkunegara., P . 2009. Human resources management. Bandung, ID: PT. Remaja Rosdakarya. Marwansyah,. 2012. Human resources management. Bandung, ID: Alfabeta.

Oshagbemi, T. 2003. Personal correlates of job satisfaction: Empirical evidence from UK universities. International Journal of Social Economics, 30(12): 1210-1232. DOI: 10.1108/03068290310500634

Riduwan. D.K \& Ahmad, E. 2007. How to use and wear a path analysis. Bandung, ID: Alfabeta.

Rivai.,V. 2008. Human Resources managementfor the enterprise. Jakarta, ID: PT Raja GrafindoPersada.

Robbins, P.S. 2007. Organizational behavior. New Jersey, NJ: Pearson Prentice-Hall.

Saleem, Y., Kamran, M.R., Sabir, F. \& Iqbal, J. 2013. career development an imperative of job satisfaction and career commitment: empirical evidence from Pakistani employees in banking sector. Career Development, 5(21): 108-118.

Siagian, S.P. 2014. Human resources management. Jakarta, ID: Bumi Aksara.

Sudarmanto. 2009. The performance and development of human resources competencies: Theory, dimensional measurement, and implementation in organizations. Yogyakarta, ID: Pustak Pelajar. 